\title{
KARHULA HOT GAS CLEANUP TEST RESULTS
}

Authors:

T. E. Lippert

Corf- $9406131--35$

G. J. Bruck

J. Isaksson (Ahlstrom)

\section{Contractor:}

Westinghouse Electric Corporation

Science and Technology Center

1310 Beulah Road

Pittsburgh, Pennsylvania 15235

\section{Contract Number:}

DE-FC21-89MC26042

\section{Conference Title:}

Coal-Fired Power Systems 94 -- Advances in IGCC and PFBC Review Meeting

\section{Conference Location:}

Morgantown, West Virginia

\section{Conference Dates:}

June 21-23, 1994

\section{Conference Sponsor:}

U.S. Department of Energy, Office of Fossil Energy, Morgantown Energy Technology Center 


\section{DISCLAIMIER}

This report was prepared as an account of work sponsored by an agency of the United States Government. Neither the United States Government nor any agency thereof, nor any of their employees, makes any warranty, express or implied, or assumes any legal liability or responsibility for the accuracy, completeness, or usefulness of any information, apparatus, product, or process disclosed, or represents that its use would not infringe privately owned rights. Reference herein to any specific commercial product, process, or service by trade name, trademark, manufacturer, or otherwise does not necessarily constitute or imply its endorsement, recommendation, or favoring by the United States Government or any agency thereof. The views and opinions of authors expressed herein do not necessarily state or reflect those of the United States Government or any agency thereof.

This report bas been reproduced directly from the best available copy.

Available to DOE and DOE contractors from the Office of Scientific and Technical Information, 175 Oak Ridge Turnpike, Oak Ridge, TN 37831; prices available at (615) $576-8401$.

Available to the public from the National Technical Information Service, U.S. Department of Commerce, 5285 Port Royal Road, Springfield, VA 22161; phone orders accepted at (703) 487-4650. 


\section{DISCLAIMER}

Portions of this document may be illegible in electronic image products. Images are produced from the best available original document. 
$8 a .2$

\section{Karhula Hot Gas Cleanup Test Results}

CONTRACT INFORMATION

Contract Number.

Contractor

Contractor Project Manager

Principal Investigators

METC Project Manager

Period of Performance

Schedule and Milestones
DE-FC21-89MC26042

Westinghouse Electric Corporation

Science \& Technology Center

1310 Beulah Road

Pittsburgh, PA 15235

(412) $256-2210$

Thomas E. Lippert

Gerald J. Bruck

Juhani Isaksson (Ahlstrom)

Richard A. Dennis

October 1992 thru September 1994

Schedule and Milestones FY94

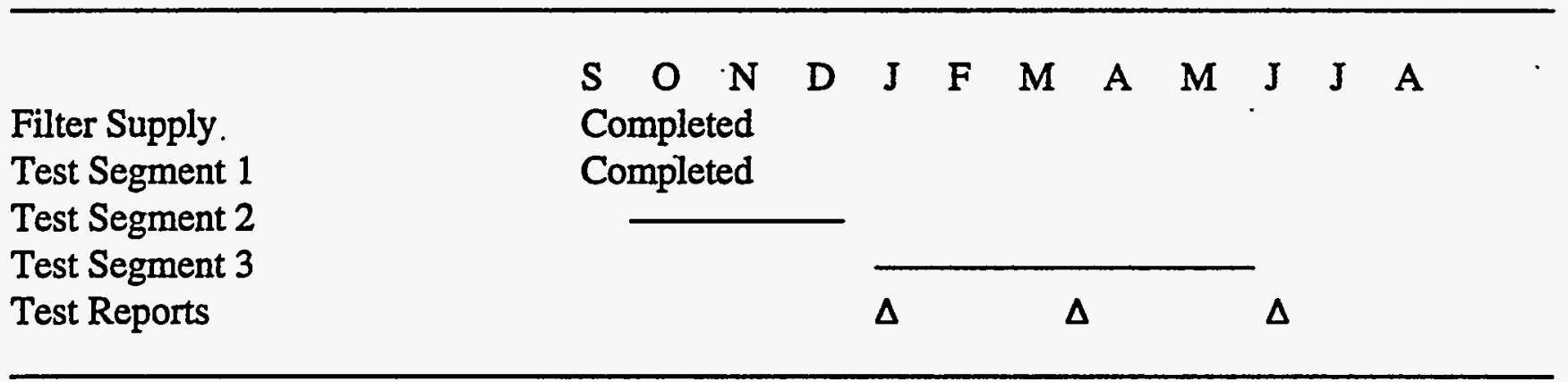

\section{OBJECTIVES}

The objective of this work is to develop a practical hot gas filter design that meets the performance and operational requirements of pressurized fluidized bed combustion - bubbling bed, circulating bed and second generation applications. The Westinghouse hot gas candle filter system is currently installed in the Ahlstrom Pyropower $10 \mathrm{MW}$ (thermal) pressurized circulating fluidized bed combustor (PCFB) test facility located in Karhula, Finland. The overall objective of the testing is to evaluate the filter design and operating reliability for selection and implementation into the Midwest Power DMEC-1 PCFB $150 \mathrm{MW}_{\mathrm{e}}$ repowering project (Clean Coal III Selection).

\section{BACKGROUND INFORMATION}

High temperature particulate filters are a key component in the advanced, coal based gas turbine cycles (IGCC and PFBC) that are 
currently under development by DOE/METC for clean coal demonstration and future commercialization. In these applications the hot gas particulate filter protects the downstream heat exchanger and gas turbine components from particle fouling and erosion effects and cleans the gas sufficient to meet environmental particulate emission requirements (Newby et al., 1992). Both PFBC and IGCC plants benefit because of lower cost downstream components, improved energy efficiency, lower maintenance and the elimination of additional and expensive flue gas treatment systems.

Ceramic barrier filter devices such as candles and cross flow filters are under development for hot gas filter application. These devices have been shown to be basically absolute filters on ash material, can be operated at relatively high gas throughput with acceptable pressure drop and cleanable by simple reverse pulse jet methods. Clay bonded silicon carbide ( $\mathrm{SiC}$ ) candle filters are commercially available. The structure of these elements is mainly a coarse-grained $\mathrm{SiC}$ bonded by a clay-based glass binder. Each element is provided with a fine grained $\mathrm{SiC}$ and aluminosilicate fiber outer skin that serves as the filtration surface. Alternate, oxide based ceramic materials are also being developed for ceramic barrier filter application. Both first generation, full scale cross flow and candle filter elements have been constructed using a homogeneous sintered structure that is an alumina/mullite (A/M) matrix containing a small percentage of amorphous (glass) phase. Laboratory and field evaluation of these and other materials are being conducted to identify, characterize and compare their respective chemical and thermal stability for IGCC and PFBC applications (Alvin et al., 1992).

Westinghouse is developing system designs to effectively package and operate these barrier filter elements and exploit their beneficial operating features (Lippert et al., 1993). An important aspect of the filter system development includes the selection and qualification of the ceramic filter element and the implementation and integrated operation of these filters in pilot plant IGCC and PFBC facilities. Hot gas filters have been implemented and operated in four different test facilities: Subpilot scale entrained gasifier, located at the Texaco Montebello Research facilities in California, Foster Wheeler Advanced Pressurized Fluidized Bed Combustion pilot plant facilities, located in Livingston, New Jersey, Slipstream of the American Electric Power (AEP) $70 \mathrm{MW}$ (electric) Tidd-PFBC, located in Brilliant, Ohio, and in the Ahlstrom $10 \mathrm{MW}$ (thermal) Circulating PFBC facility, located in Karhula, Finland (Lippert et al., 1993). Table 1 identifies and summarizes the key operating characteristics of these facilities and the type and scale of filter unit tested. This paper updates the results of the pilot plant testing currently being conducted at the Ahlstrom Pyropower PCFB facility.

\section{PROJECT DESCRIPTION}

Ahlstrom Pyropower has designed and built a pilot-scale $34 \mathrm{~mm}$ Btu/hr Pressurized Circulating Fluidized Bed (PCFB) Combustor Ceramic Barrier Filter Testing Facility in Karhula, Finland. This facility is a key tool for verifying the design and scaleup parameters of the first commercial scale PCFB, a repowering demonstration planned by Midwest Power Co. of Des Moines, awarded under Round 3 of the Department of Energy Clean Coal Technologies Program. A key aspect of the PCFB testing is the evaluation of the ceramic barrier filter technology.

In 1989, Electric Power Research Institute (EPRI) and Pyropower Corporation (PPC) signed an agreement (RP3161-1) for EPRI's support in the testing of Asahi Ceramic Tube Filter (ACTF) on the Ahlstrom's $10 \mathrm{MW}_{\text {th }}$ PCFB pilot plant. The testing of ACTF was completed in June 1992. 
Table 1. Characteristics of Coal Based Test Facilities Used in Hot Gas Filter Testing

\begin{tabular}{|c|c|c|c|c|c|}
\hline & $\begin{array}{l}\text { Entrained } \\
\text { Gasifier }\end{array}$ & $\begin{array}{l}\text { Advar } \\
\text { (Foster }\end{array}$ & $\begin{array}{l}\text { d PFBC } \\
\text { (heeler) }\end{array}$ & PFBC & PCFB \\
\hline & (Texaco) & Carbonizer & Combustor & (AEP-Tidd) & (Ahlstrom) \\
\hline $\begin{array}{l}\text { Facility Size } \\
\text { Coal Type }\end{array}$ & $\begin{array}{l}<\mathrm{MW}_{\mathrm{t}} \\
\mathrm{Pgh} \# 8\end{array}$ & $\begin{array}{l}2 \mathrm{MW}_{\mathrm{t}} \\
\text { Varied }\end{array}$ & $\begin{array}{l}1.2 \mathrm{MW}_{\mathrm{t}} \\
\text { Varied }\end{array}$ & $\begin{array}{l}10 \mathrm{MW}_{\mathrm{e}} \\
\mathrm{Pgh} \# 8\end{array}$ & $\begin{array}{l}10 \mathrm{MW}_{\mathrm{t}} \\
\text { Varied }\end{array}$ \\
\hline Coal Feed Method & Slurry & Dry & Dry & Paste & Paste \\
\hline Oxidant & $\mathrm{Air} / \mathrm{O}_{2}$ & Air & Air & Air & Air \\
\hline Process Gas & Reducing & Reducing & Oxidizing & Oxidizing & Oxidizing \\
\hline $\begin{array}{l}\text { Method of Sulfur } \\
\text { Control }\end{array}$ & External & In Bed & In Bed & In Bed & In Bed \\
\hline Precleaning & None & None & None & Cyclone & None \\
\hline Filter Unit(s) & $\begin{array}{l}\text { Cross Flow } \\
\text { Candle }\end{array}$ & $\begin{array}{l}\text { Cross Flow } \\
\text { Candle }\end{array}$ & $\begin{array}{l}\text { Candle } \\
\text { (Cross Flow) }\end{array}$ & Candle & Candle \\
\hline Filter & Full Flow & Full Flow & Full Flow & Full Flow & Full Flow \\
\hline Arrangement & With Bypass & No Bypass & No Bypass & No Bypass & No Bypass \\
\hline Status & Completed & Ongoing & Ongoing & Ongoing & Ongoing \\
\hline
\end{tabular}

PPC, in cooperation with American Electric Power Service Corporation (AEP), the U.S. Department of Energy (DOE), Electric Power Research Institute (EPRI), and Westinghouse Electric Corporation (WEC), have developed a program for testing of the Westinghouse Candle Filter (WCF). The Westinghouse Candle Filter is being tested in tandem with the PCFB combustor. Testing was initiated in the Fall of 1992. The agreement between EPRI and PPC was modified in the summer of 1992 to include continued support of EPRI for the WCF testing. EPRI's participation has included supply of coal and technical consultation. The design and supply of the Westinghouse candle filter unit was conducted in support of the cooperative agreement (DEFC21-89MC26042) between the American Electric Power Service Corporation and U.S. Department of Energy. Westinghouse is cost sharing operation of the test facility.
The prime objectives of the WCF test program are:

I. To demonstrate a commercial scale HTHP filter to operate at the downstream of a PCFB.

II. To study the performance characteristics of the filter with specific reference to:

- pressure drop across the candle elements as a function of gas velocity, dust loading, pressure, temperature, and time of operation

- pulse cleaning frequency, air pressure and quantity required.

III. To establish the reliability of the system by monitoring:

- the effect of cleaning under different operating conditions 
- the collection efficiencies

- the mechanical capability to withstand normal and abnormal operation transients such as startup, part load, load change, loss of load reflected by sudden drop in pressure or emergency shutdown, and normal shutdown

- the aging of the filter material and metal specimens

- the degradation in physical and chemical properties, if any, due to chemical effects and mechanical disturbances

- the limits of the material to withstand chemical and mechanical extremes

- the downstream dust loading.

The PCFB facility, schematically shown in Figure 1, consists of five major components: compressor, circulating bed combustor, barrier filter, flue gas cooler and pressure reduction station. High pressure air is used to burn coal in the circulating bed combustor unit. The high temperature, high pressure product gases, containing significant particulate (ash/sorbent), pass through the high temperature barrier filter, are then cooled prior to pressure reduction and discharged through the plant stack. The barrier filter removes substantially all of the particulates entrained in the hot flue gas stream.

The primary design parameters for the test facility are given in Table 2. The PCFB test facility is started by first burning natural gas. Air is provided by an electrically driven, radial fourstage compressor. As the plant pressure is increased, the gas burner is switched off and heavy fuel oil is fed into the combustor. When adequate bed temperature and plant load are achieved, coal is fed into the furnace as a paste. The paste is a mixture of crushed coal, sorbent and water. Bed material (either sieved natural sand or limestone) is injected through a separate pneumatic line into the combustor. Solids recycle is achieved with a cyclone unit housed within the combustor pressure vessel.

\section{Table 2. PCFB Test Facility Design Parameters}

$\begin{array}{lll}\text { Thermal Rating } & 34 \mathrm{~mm} \mathrm{Btu} / \mathrm{hr} & 10 \mathrm{MW}_{\text {th }} \\ \text { Fuel Feed (Max) } & 15870 \mathrm{lb} / \mathrm{hr} & 3 \mathrm{~kg} / \mathrm{s} \\ \text { Air Flow (Max) } & 43650 \mathrm{lb} / \mathrm{hr} & 5.5 \mathrm{~kg} / \mathrm{s} \\ \text { Operating Temperature } & 1615^{\circ} \mathrm{F} & 880^{\circ} \mathrm{C} \\ \text { Operating Pressure (Max) } & 232 \mathrm{psia} & 16 \mathrm{bar}\end{array}$

The Westinghouse candle filter unit, schematically shown in Figure 2, installed in the Ahlstrom facility, was backfitted to the pressure vessel previously housing the Asahi ceramic tube filter unit. The Westinghouse unit consists of a single filter cluster containing 128 candle elements that are arrayed on three plenums. The top and middle plenums each contain 38 candles. The bottom plenum contains 52 candle elements. The total filter surface area is approximately $384 \mathrm{ft}^{2}\left(35.7 \mathrm{~m}^{2}\right)$. The three plenum sections connect to a common support pipe and hot seal plate arrangement that hangs from a water cooled tubesheet. The water cooled tubesheet is integral with the pressure vessel. The tubesheet and seal plate arrangement form the separation between the dirty and clean gas chambers inside the pressure vessel. The filters are cleaned on-line by high-pressure air pulses that are controlled by fast acting valves and directed through pulse pipes that are connected through the pressure vessel and terminate at the outlet side of the filter seal plate. Three pulse pipes are provided, corresponding to the three plenum sections. Air for the pulse cleaning is provided by a booster compressor (from the main plant air source) that discharges to a high pressure reservoir. 


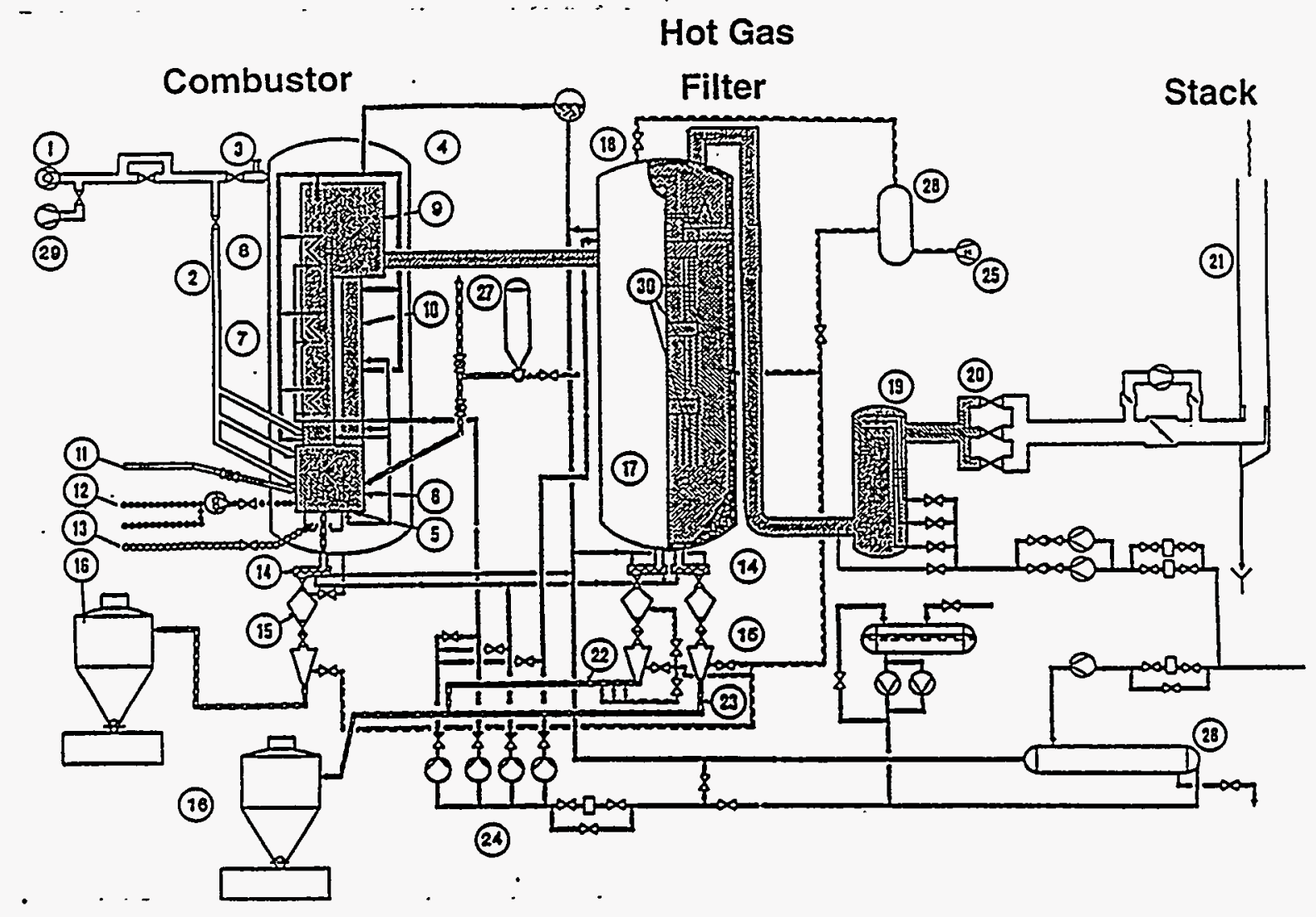

Figure 1. Ahlstrom/Karhula PCFB - HGF Test Facility

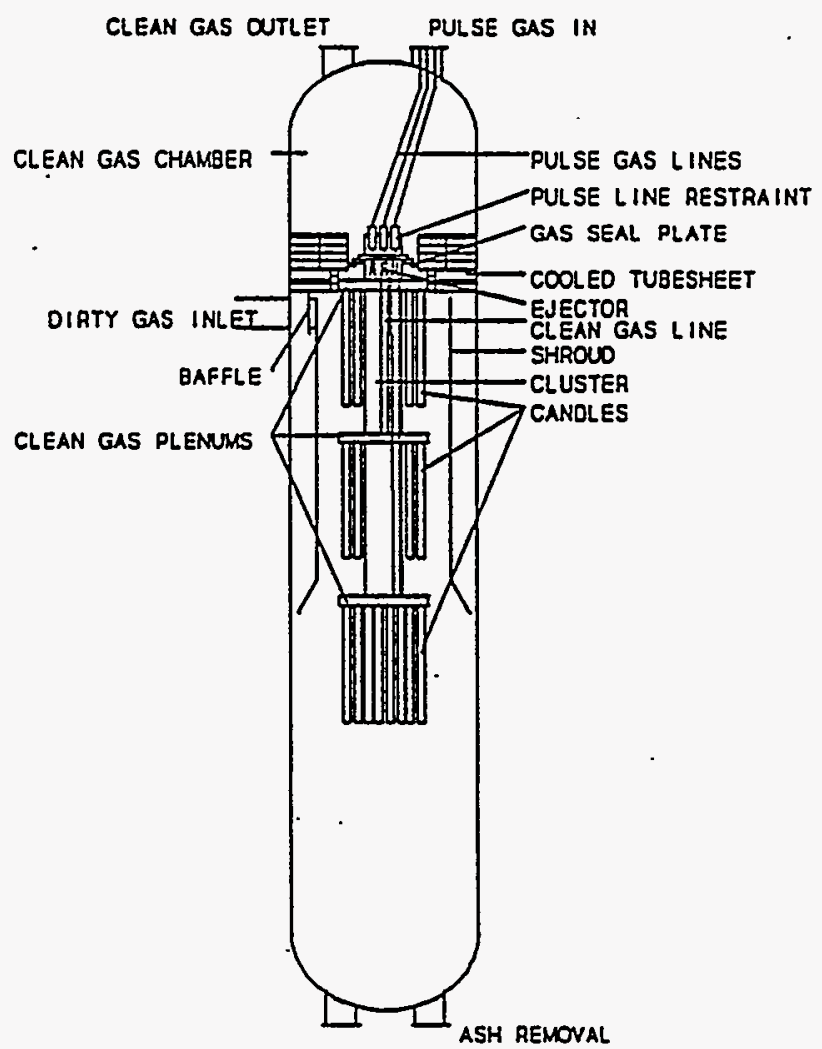

Figure 2. Schematic of PCFB Hot Gas Candle Filter 
The test facility and filter unit are instrumented to monitor the key process and filter performance parameters. Measurements include gas flow, system pressure, filter pressure drop, gas temperatures, metal temperatures, and reservoir pressure.

The Westinghouse filter was installed in September 1992 and operated in accordance with schedule given in Figure 3. The testing is divided into three segments with the goal of achieving between 500 to 1000 hours operation in each segment. To date a total of 1741 hours of coal operation has been achieved, Table 3. Test segments 1 and 2 have been completed while testing in segment 3 is ongoing. Results from the first test segment have been reported (Lippert, et al., 1993).
Following Test Segment 1 operation several facility and filter modifications were implemented to address expected root cause events that had resulted in candle element damage during this testing. These modifications addressed the occurrence of process upsets and thermal transient events and include:

- improved main air compressor surge control

- increased the range of control to the fuel feed pump

- improved pulse valve operation

- improved distribution of the gas flow entering the filter unit by modifying the inlet baffle and shroud.

\begin{tabular}{|c|}
\hline Year \\
\hline Month \\
\hline Filter Modiflcation \\
Test Segment I \\
- Illinols \#6 Coal \\
- lowa Rawhide Coal \\
- Newland Coal \\
- Kentucky Coal \\
Test Segment II \\
- Illinols \#6 Coal \\
- Black Thunder Coal \\
Test Segment III \\
- Black Thunder Coal
\end{tabular}

Figure 3. Westinghouse Filter Testing - Karhula PCFB Schedule 
Table 3. Summary of Westinghouse Hot Gas Filter Operation at the Ahlstrom PCFB Facility - Karhula

\begin{tabular}{|c|c|c|c|c|}
\hline Coal & $\begin{array}{c}\text { Segment } 1 \\
\text { (Hours) }\end{array}$ & $\begin{array}{c}\text { Segment } 2 \\
\text { (Hours) }\end{array}$ & $\begin{array}{c}\text { Segment } 3 \\
\text { (Hours) }\end{array}$ & Total \\
\hline Illinois No. 6 & 85 & 221 & - & 306 \\
\hline lowa Rawhide & 61 & - & - & 61 \\
\hline Newland & 300 & - & - & 300 \\
\hline Kentucky & 270 & - & - & 270 \\
\hline Black Thunder & $=$ & 291 & $\underline{513}$ & 804 \\
\hline Total Coal & $\begin{array}{l}716 \\
\cdots\end{array}$ & 512 & 513 & 1741 \\
\hline
\end{tabular}

\section{RESULTS}

This section summarizes Test Segment 2 results and current status of Test Segment 3. During 1026 hours of operation represented by Test Segment 2 and current testing in Test Segment 3, the filter unit and test facility has performed very well and operated without major equipment failures. The filter has demonstrated stable pressure drop and has operated without candle failure. Tables 4 and 5 summarize the filter operating parameters during the Test Segments 2 and 3, respectively. In Test Segments 2 and 3, commercially available clay bonded silicon carbide candle filters (Vitropore ${ }^{R}$ ) have been utilized, and filter operating conditions maintained below approximately $1560^{\circ} \mathrm{F}$ $\left(850^{\circ} \mathrm{C}\right)$ to better accommodate these candles.

\section{Test Segment 2}

Test Segment 2 test runs, Table 4, were initiated on November 6,1993 and continued until December 17, 1993. Operation was initiated utilizing high sulfur Illinois No. 6 coal and an Iowa industrial No. 1 limestone sorbent. Operation on the Illinois coal consisted of a relatively short run (1 to 2 days) due primarily with coal feeding problems associated with frozen coal. Nine separate test runs were made on the Illinois coal with plant load ranging from about 65 to $75 \%$, and operating pressures between 138 to $152 \mathrm{psi}$ (9.5 to $10.5 \mathrm{bar}$ ). Stable filter operation was observed through each test segment as determined by the filter baseline pressure drop measurements. In this testing with high sulfur Illinois coal, changes of the coal paste $\mathrm{Ca} / \mathrm{S}$ (calcium to sulfur) molar ratio and load changes resulted in corresponding changes in the filter inlet dust loading ranging from 7200 to 12,300 $\mathrm{ppm}$. Under these widely varying conditions, the filter operated without issue.

The longest continuous test run on the Illinois coal was approximately 53 hours. Thus, during this period of 221 coal operating hours, the filter was cycled through nine startups and, in addition, experienced over 170 hours of additional operation on oil firing. 
Table 4. Summary of Representative Filter Operation During Karhula Test Segment 2

Filter Parameter

Coal

Sorbent

Coal Operation, hrs

Fuel Input, MW

Operating Temperature, ${ }^{\circ} \mathrm{F}$

$\left({ }^{\circ} \mathrm{C}\right)$

Filter Face Velocity, ft/min

$(\mathrm{cm} / \mathrm{s})$

Baseline Pressure Drop, in wg

(mbar)

Cleaning Cycle, $\min$

Dust Loading, ppmw
Test Segment 2 (511 Hrs) $\quad 11 / 6 / 93$ through 12/17/93

$\begin{array}{ccc}\begin{array}{c}\text { Illinois \#6 } \\ \text { lowa }\end{array} & \begin{array}{c}\text { Black Thunder } \\ \text { lowa }\end{array} & \begin{array}{c}\text { Black Thunder } \\ \text { None }\end{array} \\ 221 & 116 & 174 \\ 6.9-8.2 & 4.9-8.2 & 7.6-8.6 \\ 1470-1522 & 1333-1488 & 1471-1509 \\ (800-828) & (723-809) & (800-821) \\ 5.5-6.5 & 3.4-6.5 & 6.2-6.4 \\ (2.8-3.3) & (1.7-3.3) & (3.1-3.2) \\ 18-30 & 7-26 & 26-29 \\ (46-75) & (18-66) & (65-72) \\ 45-55 & 30 & 20 \\ 7200-12300 & 2000-6900 & 6400\end{array}$

Table 5. Sumary of Representative Filter Oepration During Karhula Test Segment 3

Filter Parameter
Coal
Sorbent
Coal Operation, hrs
Fuel Input, MW
Operating Temperature, ${ }^{\circ} \mathrm{F}$

$\left({ }^{\circ} \mathrm{C}\right)$

Filter Face Velocity, ft/min

$(\mathrm{cm} / \mathrm{s})$

Baseline Pressure Drop, in wg

(mbar)

Cleaning Cycle, $\min$

Dust Loading, ppmw
Test Segment 3* (513 Hrs) 2/7/94 through 3/20/94

Black Thunder None

258

$7.8-10$

$1490-1560$

(810 - 850)

$$
\begin{gathered}
5.9-7.9 \\
(3.0-4.0)
\end{gathered}
$$

$26-48$

$(65-120)$

$40-55$

$4000-7000$
Black Thunder

lowa Ind \#1

256

$4.6-5.1$

$1273-1327$

$(690-720)$

$3.0-4.2$

$(1.5-2.1)$

$10-14.1$

(25 - 35)

$40-55$

$3000-6000$

- Additional Testing Planned - May/June 1994 
Operation with the low sulfur Black Thunder coal included testing both with and without sorbent addition and under plant load conditions between 50 to 75 percent and system pressure ranging from 152 to $167 \mathrm{psi}$ (10.5 to $11.5 \mathrm{bar}$ ). The Black Thunder coal testing occurred in two operating segments of 53 and 238 hours. Stable filter operation was again achieved with the Black Thunder coal. The filter was operated without issue over a range of inlet loadings that depended on plant load and use of sorbent.

Following the 238 hour continuous operation on the Black Thunder coal, the filter testing was terminated by a scheduled shutdown and the unit inspected. Visual inspection showed all the candles to be intact with no ash bridging evident between candles. Ten of the bottom plenum candles were removed (and replaced) for subsequent destructive testing. Ash samples were also collected for analysis. Routine facility maintenance was performed prior to restarting of the unit, initiating Test Segment 3.

\section{Test Segment 3}

Test Segment 3 testing, Table 5, was initiated early February 1994, with continuing operation utilizing Black Thunder coal, and operating both with and without sorbent addition. The initial operation in this test segment was at full load conditions, but cold weather again resulted in frozen coal and subsequent coal feeding problems causing frequent interruptions resulting in shutdown or hot standby on oil firing. After approximately 258 hours of coal operation under this mode, plant operation was reduced and maintained to about $50 \%$ load conditions. This circumvented the issues caused by the cold weather condition and provided opportunity to obtain important filter performance and operating data at the low load conditions. With this data, the ability to extrapolate filter operating characteristics and performance over a range of conditions is improved. Later testing in this test segment will focus on full load operation.

During this testing, filter operation was stable with no pressure drop issues. Testing was terminated late March 1994 for scheduled facility maintenance. Preliminary inspection of the filter again showed the filter to be in good operating condition. No dust was present on the clean side of the filter confirming filter performance. Following the initial inspection several candle filters were removed from the bottom plenum and inspected. This inspection showed several of the candle elements to be slightly elongated and some with hairline cracks near the flange neck.

Subsequent follow-up showed the manufacturing (firing conditions) of these candles had been modified relative to standard processing. The filter elements from these manufacturing lots (approximately 45 candles) have been identified and removed and replaced with candles manufactured using standard processing. Test Segment 3 candle testing has now been resumed.

Summary. Over 1741 hours of operation have now been achieved with the Westinghouse candle filter unit operating in the Ahlstrom PCFB facility. Extended, trouble-free, operating periods have been achieved in which the candle filter unit has demonstrated excellent particle collection efficiency and stable filter pressure drop while operating over a wide range of coal/sorbent types and gas temperature to $1650^{\circ} \mathrm{F}\left(900^{\circ} \mathrm{C}\right)$.

\section{FUTURE WORK}

Operation of the Wèstinghouse candle filter unit will be continued through June 1994. Following this testing the unit will again be inspected and decisions for continued testing made. 


\section{REFERENCES}

Alvin, M. A. et al., 1992. Hot Gas Cleanup and Gas Turbine Aspects of an Advanced PFBC Power Plant. In Proceedings of the Ninth Annual Coal-Fueled Heat Engines, Advanced Pressurized Fluidized-Bed Combustion $(P F B C)$ and Gas Stream Cleanup Systems Contractors Review Meeting, p. 168, DOE/METC-93/6129.

Lippert, T. E. et al., 1993. Specific Filter Designs for PFBC. Companion paper - In Proceedings of Coal Fired Power Systems 93 - Advances in IGCC and PFBC Contractors Review Meeting, DOE/METC June 28-30, 1993.

Lippert, T. E. et al., 1993. Westinghouse Filter Update. In Proceedings of Coal Fired Power Systems 93 -Advances in IGCC and PFBC Review Meeting, DOE/METC-93,6131, p. 497.

Newby, R. A. et al., 1992. Hot Gas Cleanup and Gas Turbine Aspects of an Advanced PFBC Power Plant. In Proceedings of the Ninth Annual Coal-Fueled Heat Engines, Advanced Pressurized Fluidized-Bed Combustion (PFBC) and Gas Stream Cleanup Systems Contractors Review Meeting, p. 55, DOE/METC-93/6129. 